\title{
Working
}

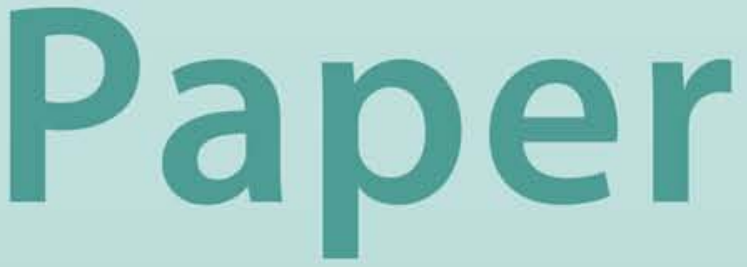




\title{
A Framework for the Surveillance of Derivatives Activities
}

\author{
Eva Gutierrez
}




\title{
IMF Working Paper
}

Policy Review Department

\section{A Framework for the Surveillance of Derivatives Activities}

\author{
Prepared by Eva Gutierrez ${ }^{1}$ \\ Authorized for distribution by Marianne Schulze-Gattas
}

March 2005

\begin{abstract}

\section{This Working Paper should not be reported as representing the views of the IMF.} The views expressed in this Working Paper are those of the author(s) and do not necessarily represent those of the IMF or IMF policy. Working Papers describe research in progress by the author(s) and are published to elicit comments and to further debate.
\end{abstract}

This paper proposes a framework for the surveillance of financial institutions' derivatives activities. The designed framework builds on information likely to be collected by financial market regulators for supervisory purposes, and/or information collected by market participants for the purpose of their own risk management. The framework involves four pillars: (i) analyzing quantitative information on Derivatives activities, (ii) determining the adequacy of prudential regulations and supervisory arrangements, (iii) assessing the risk mitigation infrastructure, and (iv) assessing the degree of market transparency of the derivatives activities of financial institutions.

JEL Classification Numbers: G19, G20

Keywords: Derivatives, surveillance, financial stability

Author(s) E-Mail Address: egutierrez@imf.org

\footnotetext{
${ }^{1}$ I want to thank Renzo Avessani, Burkhard Dress, Irit Mendelson, Salih Nefcti, and Ceyla Pazarbasioglu, as well as participants in an IMF seminar, for their comments. Any remaining mistakes are my own.
} 


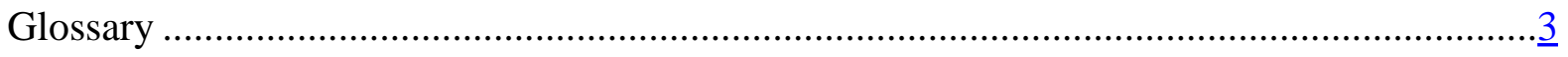

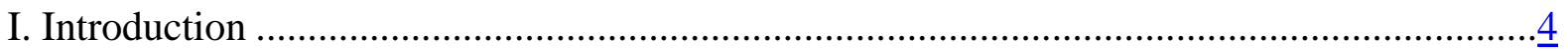

II. Derivatives Activities and Macroeconomic Stability .....................................................

III. Collecting and Analyzing Information on Derivatives Activities ................................... $\underline{6}$

A. Sources of Information on Derivatives Activities............................................... $\underline{6}$

Supervisory information.................................................................

Central bank information ................................................................. $\underline{9}$

Information disclosed by institutions........................................................... $\underline{9}$

B. Analyzing Information on Derivatives Activities ............................................10

IV. Assessing the Quality of the Prudential and Supervisory Framework ...........................19

V. Assessing the Risk Mitigation Infrastructure........................................................... 20

VI. Assessing Transparency of Derivatives Activities ................................................ 21

Tables

1. Notional Amounts by Underlying Exposures .........................................................12

2. Turnover and Notional Outstanding Amounts of Domestic Derivative Markets ............14

3. Derivative Contracts’ Notional Amounts by Remaining Maturity ............................... 15

4. OTC Notional Amounts, Market values and Potential Credit Exposures .......................16

5. Information on Credit Quality of OTC Derivative Contracts ......................................17

6. Information about Past-due Derivatives and Credit Losses......................................17

7. Summary of derivatives data elements and their uses ............................................

\section{Boxes}

Box 1. BIS Survey of Disclosure Practices by Banks: Disclosure of Derivatives Activities...23

References... 


\section{GLOSSARY}

$\begin{array}{ll}\text { BC } & \text { Basel Committee } \\ \text { BCPs } & \text { Basel Core Principles } \\ \text { BIS } & \text { Bank for International Settlements } \\ \text { CCPs } & \text { Central Counter Parties } \\ \text { CDSs } & \text { Credit Default Swaps } \\ \text { CGFS } & \text { Committee on the Global Financial System } \\ \text { CMF } & \text { Common Minimum Framework } \\ \text { CPSS } & \text { Committee for Payment and Settlement Systems } \\ \text { ECSC } & \text { Euro-Currency Standing Committee } \\ \text { EU } & \text { European Union } \\ \text { FSAP } & \text { Financial System Assessment Program } \\ \text { IAIS } & \text { International Association of Insurance Supervision } \\ \text { IOSCO } & \text { Organization of Securities Commissions } \\ \text { ISDA } & \text { International Swap Dealers Association } \\ \text { OTC } & \text { Over-the-Counter } \\ \text { VaR } & \end{array}$




\section{INTRODUCTION}

Derivative markets have increased dramatically during the last years. The Bank for International Settlements (BIS) reports that the global market for over-the-counter (OTC) derivative products has grown from a notional outstanding of US\$80 trillion in 1998 to US\$197 trillion in 2003. Outstanding notional amounts of exchange-traded derivatives grew form US\$14 trillion to US\$37 trillion during the same period, bringing the total amounts standing to US\$234 trillion. ${ }^{2}$ While derivatives activities facilitate risk hedging and risk transfer to institutions more willing to bear the risks, there are also risks involved in derivatives activities. Monitoring information on the derivatives activities of financial institutions in developed and emerging markets would help IMF economists to evaluate the degree of risk transfer in the economy and the accumulation of risks that could create potential macroeconomic vulnerabilities.

This paper proposes a framework for the surveillance of financial institutions' derivatives activities. The designed framework builds on information likely to be collected by financial market regulators for supervisory purposes, and/or information collected by market participants for the purpose of their own risk management that it is typically publicly disclosed or that could be collected through a survey. The proposed framework has four pillars: (i) analyzing quantitative information on derivatives activities, (ii) determining the adequacy of prudential regulations and supervisory arrangements, (iii) assessing the risk mitigation infrastructure by auditing the existence and legal enforceability of master agreements, collateral, and margin agreements, and lastly (iv) assessing the degree of market transparency, conducive to market discipline, of the derivatives activities of financial institutions by evaluating the information publicly disclosed by the institutions themselves and the supervisors. While the proposed framework will provide information regarding possible vulnerabilities arising from derivatives activities, it is also important to recognize the limitations of any such framework to accurately predict episodes of systemic distress. ${ }^{3}$

The paper is structured as follows. Section II summarizes the implications for macroeconomic stability of derivatives activities. Section III provides an overview of the information typically collected by regulators and disclosed by market participants and proposes a framework for collecting and analyzing information on domestic derivative markets in the context of MFD surveillance. Section IV refers to international best practices regarding prudential supervision of derivatives activities. Section V indicates the type of risk mitigating mechanisms for derivatives activities that should be evaluated, and where to obtain information on the quality of those mechanisms. Finally, Section VI describes disclosure practices standards that foster market discipline.

\footnotetext{
${ }^{2}$ See BIS Quarterly Review, “International Banking and Financial Market Developments.”

${ }^{3}$ For example, some private sector participants indicated that "few if any standardized forms of regulatory reporting can anticipate emerging sources of significant potential market problems, let alone systemic risks.” See “Improving Counterparty Risk Management Practices,” prepared by the Counterparty Risk Management Group.
} 


\section{Derivatives ACTIVITIES AND MACROECONOMIC STABILITY}

Derivatives are thought to improve economic efficiency by facilitating the reallocation of risks to those more willing to bear them. The possibility of transferring risks reduces the cost of risky activities and investment. At the same time, derivatives facilitate leverage and the concentration of risks in certain sectors or institutions. ${ }^{4}$ Lack of transparency in OTC derivatives markets may result in an accumulation of risks in certain institutions, making more difficult the judgment by other participants on the likely actions of heavily exposed counterparties. Abrupt movements in prices could result in a dry up of liquidity for heavily exposed counterparties, which could in turn trigger the unwinding of positions by other market participants resulting in a bank run type of scenario.

Information on derivatives activities of main market participants is necessary to get an accurate idea of the institution exposures to market, credit and liquidity risk and to anticipate potential systemic problems. ${ }^{5}$ Market risk reflects potential losses due to movements in market prices. Credit risk is the risk in the failure of a counterparty, including settlement risk. There are two types of liquidity risks. Funding liquidity risk is the risk that an institution cannot meet its payments or margin calls on time. Market liquidity risk is the risk that a position cannot be unwound without significant loss. While an institution incurs both credit and market risk when engaging in derivatives activities regardless of the whether the transactions occur in the international or in the domestic market, liquidity risk depends on market characteristics. ${ }^{6}$

In addition, aggregated statistics on the international and domestic derivatives markets are of significant value to infer the overall activity in the market and the relative exposure of the different participants. Information on market liquidity is also useful to assess market liquidity risks arising from derivative products traded in a particular market.

Derivatives also affect monetary policy formulation and implementation, by affecting the speed of market movements, the responsiveness of agents to movements in interest and exchange rates, affecting the information content of traditional monetary policy instruments,

and providing new indicators that can affect monetary policy. ${ }^{7}$ Derivatives might reduce the effect of monetary policy decisions through the lending channel and exchange rate channel. For example, derivatives might reduce the pass through between policy rates and lending

\footnotetext{
${ }^{4}$ There are concerns that some new products such as credit derivatives, might result in the transfer of risks to institutions which are less equipped to deal with those risks.

${ }^{5}$ While these risks are not exclusive to derivatives activities, the growth and complexity of these activities poses problems both for firms and supervisors.

${ }^{6}$ As in any other operations, operational and legal risks are also present.

7 See CGFS (1994).
} 
rates if firms tend to swap floating for fixed rates. Equally, firms might be unaffected by movements in the exchange rate to the extent that they use exchange rate derivates for hedging purposes. Information on the extent of hedge exposures, and the market in which the products are traded is important to assess the likely direction of these effects.

\section{COLLECTING AND ANALYZING INFORMATION ON DERIVATIVES ACTIVITIES}

\section{A. Sources of Information on Derivatives Activities}

The main sources of information for derivatives activities are supervisory information, central bank surveys of aggregate market activity, and information disclosed by institutions in their annual reports.

\section{Supervisory information}

Although some nonfinancial firms are particularly active in derivative trading, as illustrated by ENRON, financial institutions are typically the most active participants in derivative markets. Banks, securities firms, and insurance firms are supervised by the financial authorities that periodically request information to assess risk exposures. For these institutions supervisory information may be obtained on aggregate basis to avoid confidentiality issues. However, there are also unsupervised financial institutions, such as hedge funds, which actively trade derivatives and for which information might not be available.

Banks and securities firms engage in derivatives trading as market makers (hold a balance portfolio and make profits from fees and differences in spreads), as do arbitrageurs (profiting from small differences in prices in similar products across different markets) and positiontakers. Main banks and securities firms in the world are market makers in the OTC markets, typically called dealers, while smaller institutions and investment funds are end-users, for the purpose of arbitrage or position-taking. Dealers take on risks that other entities (both financial and corporate) are unwilling to bear, or sell products to customers for investment purposes. The positions they take are either maintained to hedge some other risks already on their books, or traded with other dealers. Insurance firms are also heavily involved in derivative transactions, particularly as writers of credit default swaps (CDSs); however, they mostly tend to participate as end-users for the purpose of hedging in other types of derivative transactions. ${ }^{8}$ For example, European Union (EU) directives limit insurers Derivatives

\footnotetext{
${ }^{8} \mathrm{~A}$ CDS is a specific kind of counterparty agreement which allows a lender to transfer the credit risk of a third party to the writer of a CDS, who agrees to insure this risk in exchange of regular periodic payments (insurance premium). If the third party defaults, the party providing insurance will have to purchase from the insured party the defaulted asset. CDSs, either referring a specific bond, or to a basket of bonds, account for 75 percent of the credit derivative market, the fastest growing segment of OTC derivatives.
} 
activities to efficient risk management or risk reduction purposes, which in practice translate to holding derivatives for hedging purposes. Credit derivatives can be considered as investment products, and therefore the limits to their holdings are less strict. Although the industry is a significant player on the global market of CDSs, it appears that credit derivatives may be a relatively small proportion of insurers investment activities. ${ }^{9}$

Banks and securities supervisors in most of the G-10 countries have implemented the supervisory information framework recommended by the Basel Committee and International Organization of Securities Commissions (IOSCO) in 1998. The framework consists of i) a catalogue of data identified as important for an evaluation of derivatives risks, and (ii) a common minimum framework (CMF) of data elements (subset of the catalogue) to which supervisors should have access. The CMF is applied to internationally active institutions with significant derivatives operations, although there is flexibility to extend the framework to other institutions with significant derivatives activities. Quantitative information on Derivatives activities in the catalogue aims to address credit, liquidity and market risks, as well as their effect on earnings. Given the decrease in credit risk achieved in exchange-traded derivatives, supervisors tend to concentrate on collecting information on OTC derivatives. ${ }^{10}$ The information collected also helps to monitor the volume of activities and trends on how derivatives are used by institutions. The framework also encourages supervisors to collect qualitative information regarding risk management systems and exposure limits of institutions.

Even in countries not subscribed to the CMF information on replacement cost of positions, which allows the assessment of credit risk, is available for banks under the 1988 Basel Capital Accord calculating credit exposure under the current exposure method, as well as notional information to calculate the add-ons by type of product and maturity. ${ }^{11,12}$ To assess

\footnotetext{
${ }^{9}$ See IAIS (2003).
}

${ }^{10}$ Credit risk is lower in case of exchange-traded derivatives, where the clearing houses employ techniques to mitigate risks such as full collateralization in the case of written options and daily settlement of exposures in the case of futures.

11 The 1988 capital accord allows for calculation of credit exposures under any of two different methods. Under the current exposure method it is measured as the sum of the current and potential credit exposure. The current credit exposure reflects the replacement cost of the position (valued at market prices). The potential credit exposure, measuring potential exposures due to changes in the underlying, is an add-on calculated as a percentage of the notional principal amount of its book split by its residual maturity. Under the original exposure method the banks apply conversion factors to the notional principal amounts of each instrument according to is original maturity. Exposures should reflect master netting agreements and credit enhancements such as collateral or guarantees to the extent they are legally enforceable.

${ }^{12}$ Notional amounts for certain products largely differ from credit exposures. For example, in an interest rate swap the notional principal amount refers to the predetermined amount on 
market risk for institutions which are not major dealers, position data can be obtained from the framework for the Basel Committee's standardized approach for market risk. This information includes (i) net long or short position by currency, (ii) net long or short position by commodity type, (iii) long and short equity positions broken down by major markets and issuers, (iv) long and short positions of interest rate derivatives broken down by time-bands according to residual maturity, and breakdown of gross positions (i.e., replacement cost of the positions, marked to market) by issuer, and (v) delta equivalents of portfolios of options as well as gamma and vega risk (for banks using the delta-plus method). ${ }^{13}$ Information for sophisticated players can be drawn from their internal models.

In addition to the information available to calculate capital charges under the current Basel Accord, the minimum framework recommended by the Basel Committee contains: ${ }^{14}$

- A table with information on notional amounts by broad category of risk (i.e., interest rate, foreign exchange, commodities and equity-linked contracts) and by instrument type (i.e., forwards, swaps, and options). The information illustrates the scope and nature of the institution activities, whether is primarily involved on exchange or OTC markets and whether derivatives are used for trading or hedging purposes.

- $\quad$ A table with the minimum information to assess market values (gross positive/negative) by broad risk category, distinguishing contracts for purposes other that trading. This information complements the former table in providing a sense of the involvement of the institution in the market. It also indicates the gains and losses in the derivatives book.

- A table on the notional amounts of derivatives by risk category and maturity.

- $\quad$ A table on the credit exposure (before and after collateral and guarantees) by counterparty credit quality. This information enhances the understanding of an

which the exchanged interest payments are based. However, the notional amount is not exchanged. In addition, collateral or other risk mitigation techniques might reduce credit risk exposure.

13 The price of an option mainly depends on the price and volatility of the underlying. Both the delta and gamma of an option measure how the price of the option changes with the price of the underlying. The delta is the derivative of the price of the option with respect to the price of the underlying, and the gamma is the derivative of the delta of the option with respect to the price of the underlying. The vega of an option is the derivative of the price of the option with respect to the volatility of the underlying.

${ }^{14}$ It is recommended that reporting be made on a consolidated basis, since institutions tend to book all their derivative products of a given class in one location. 
institution's potential risk, and is also useful in assessing the concentration of credit risk on particular type of counterparties.

- $\quad$ A table on book value and gross positive market value of past-due derivatives, as well as information on credit losses on derivative instruments during the period.

- $\quad$ Maximum, minimum, and average value at risk (VaR) during the period by risk factor, as well as VaR under stress scenarios.

The International Association of Insurance Supervision (IAIS) has not issued a standardized framework, for insurance supervisors to collect information on derivatives activities. However, the supervisory standard for derivatives in the insurance industry, indicates that supervisors may wish to request the following quantitative information: ${ }^{15}$

- $\quad$ notional amounts by broad category of risk, instrument type, and trading type (i.e., exchange or OTC);

- $\quad$ market values by broad risk category, instrument type and trading type;

- $\quad$ for derivatives used in relation to the management of invested assets and liabilities, the net value of the related positions; and

- $\quad$ where derivatives are held for purposes other than management of invested assets and liabilities, additional information as appropriated using the CMF as an example.

\section{Central bank information}

To facilitate monitoring of events in derivative markets and to provide supervisors with a view of total size of market activities, many central banks also collect information on domestic Derivatives activities. Typically, they use framework based on the information contained in the CMF, with certain modifications. For example, to avoid double counting, the transaction between institutions in the reporting group should be eliminated. Typically, data reported include notional amounts by type of product and risk category, as well as turnover data. Regarding exchange-traded derivatives, exchange markets publish statistics on the value of contracts traded and turnover, however, double counting issues arise in these statistics.

\section{Information disclosed by institutions}

The Basel Committee (BC) as well as many local supervisors encourages banks, securities firms, and other market participants to provide adequate qualitative and quantitative information regarding their derivatives activities. Market discipline can reinforce the objectives of supervision by rewarding institutions that manage risks effectively and

${ }^{15}$ See IAIS (1998). 
penalizing those which are ineffective.

Regarding qualitative disclosures, under the framework recommended by the $\mathrm{BC}$ and IOSCO, the institutions should indicate in their reports whether derivatives are used mainly for trading or hedging purposes, and whether if they primarily use exchange-traded or OTC derivatives. They should also indicate whether they are market makers, arbitrageurs or position takers in the different markets. In addition, information regarding risk management policies, and a description of the accounting treatment of its derivative instrument holdings should be provided.

Quantitative aspects on which public disclosure is recommended include end-of-period notional amounts and average market values for the major categories of cash and derivative instruments held for trading and nontrading purposes. Information should be provided by broad risk category, broad instrument category (futures, forwards, swaps and options) and by repricing date, and distinguish between exchange-traded or OTC derivatives. Regarding credit risk, institutions should disclose both their gross current credit exposures (replacement cost) and potential future credit exposure to counterparties, on average over the reporting period, or in a range mode. Institutions should also disclose information on credit exposure by maturity band. If the institution is a member of a multilateral clearing organization for OTC contracts, it should report the effect of multilateral netting. Disclosure of the nominal and market value of collateral provided and aggregated information on counterparty credit quality is also recommended. Finally, if an institution uses credit derivatives, it should disclose the notional amount and credit derivative exposure by reference asset illustrating their effect. ${ }^{16}$

The IAIS has also issued guidelines for public disclosures by insurers. However, the guidelines only explicitly refer to derivatives activities to indicate that public disclosures should include a description of the use of derivatives and the effect of the economic position of the investment portfolio and liabilities. ${ }^{17}$

\section{B. Analyzing Information on Derivatives Activities}

The framework suggested builds on the information typically disclosed by institutions to supervisors and markets, and on the information disclosed by central banks and exchanges. The data compiled on the set of proposed tables complement information obtained from interviews with supervisors and market participants. The data also help to quantify the participants description of the nature of derivatives activities of mayor players in the market, trends observed, and the major type of risks arising from these activities. However, the

\footnotetext{
${ }^{16}$ However, the results of the 2001 BIS survey of disclosure practices for selected international banks indicated low levels of disclosure of effect of netting arrangements and notional and market values of trading and not trading portfolios.

${ }^{17}$ See IAIS (2002).
} 
overall risk profile of the sector or institutions has to be assessed in a portfolio approach that incorporates cash and related derivative positions.

All tables in the proposed framework, except for Table 2, generally follow the format of tables under the CMF, and therefore they are available in countries subscribed to it. Virtually all the information in the tables should be available for banks and securities firms in G-10 countries, since they subscribe to the CMF. In some instances, information might be available for insurance firms although it is less likely. In addition, VaR information needs to be collected to assess the overall market risk profile.

Although supervisory information on an individual institution basis might be subject to confidentiality issues, information could be requested at the aggregate level. Where banks, securities and insurance are active participants, information can be requested from the respective supervisors at the sector level. This would help to understand the relative participation of the different institutions in derivatives activities, and to understand the type of transactions and exposures at the sectoral level. Information should also be requested for the largest players (e.g., 3, 5, or 10) to assess concentration effects. Also, staff can construct some aggregated information based on the data disclosed by market participants in their annual reports or by submitting a survey to financial institutions. The information contained in these tables should be collected for the last three to five years, at the highest available frequency to form an idea of trends and evolution of activities.

Notional amounts, although not reflecting risk exposures, help to track the size of the market for classes of derivative instruments and provide and indication of the gross transfer of market risk through different instruments. Table 1, presents information on notional amounts for exchanged traded and OTC derivatives, by factor risk and by type of product. ${ }^{18}$ The table also indicates the proportion of contracts traded domestically and internationally, and the proportion of products held for trading. Comparison between the data in Table 1 and the BIS and International Swap Dealers Association (ISDA) surveys can be used to assess the share of domestic financial institutions on global derivative markets, and also to identify how the composition of derivative products held in books of institutions operating in the domestic financial system compare to the products traded by institutions worldwide. ${ }^{19}$

${ }^{18}$ The tables in these section present the format proposed to compile data on Derivatives activities from financial supervisors and institutions.

${ }^{19}$ Compilation of the main sources for derivatives data can be found at http://www.financialpolicy.org/dscdata.htm. For comparability purposes, it is important to check that the collected data and global survey data treat equally the transactions among institutions in the reporting group. For example, BIS data is adjusted to avoid double counting of transactions among institutions in the reporting group, and data are collected at the consolidated level not accounting for intra-group transactions. Bankscope also constitutes a source for international comparison of banks derivatives activities. Some banks in G-10 countries report in Bankscope notional amounts of derivatives and in some cases whether they are held for trading or other purposes. 
Table 1. Notional Amounts by Underlying Exposures

\begin{tabular}{|c|c|c|c|c|c|}
\hline Notional Amounts & $\begin{array}{l}\text { Interest } \\
\text { Rate } \\
\text { Contracts }\end{array}$ & $\begin{array}{c}\text { Foreign } \\
\text { Exchange and } \\
\text { Gold Contracts } \\
1 /\end{array}$ & $\begin{array}{c}\text { Commodity } \\
\text { Contracts }\end{array}$ & $\begin{array}{l}\text { Equity- } \\
\text { linked } \\
\text { Contracts }\end{array}$ & $\begin{array}{c}\text { Credit } \\
\text { Derivatives }\end{array}$ \\
\hline \multicolumn{6}{|l|}{ OTC contracts } \\
\hline \multicolumn{6}{|l|}{ Forwards } \\
\hline \multirow{2}{*}{\multicolumn{6}{|c|}{$\begin{array}{l}\text { Swaps } \\
\text { of which : Plain }\end{array}$}} \\
\hline & & & & & \\
\hline \multicolumn{6}{|l|}{ Purchased options } \\
\hline \multicolumn{6}{|l|}{ Written options } \\
\hline \multicolumn{6}{|l|}{ Credit Default Swaps } \\
\hline \multicolumn{6}{|l|}{ Other } \\
\hline \multicolumn{6}{|l|}{ Exchange-traded contracts } \\
\hline \multicolumn{6}{|l|}{ Futures - long positions } \\
\hline \multicolumn{6}{|l|}{ Futures - short positions } \\
\hline \multicolumn{6}{|l|}{ Purchased options } \\
\hline \multicolumn{6}{|l|}{ Written options } \\
\hline \multicolumn{6}{|l|}{ Other } \\
\hline \multicolumn{6}{|l|}{$\begin{array}{l}\text { Total contracts traded } \\
\text { internationally }\end{array}$} \\
\hline \multicolumn{6}{|l|}{$\begin{array}{l}\text { of which OTC } \\
\text { contracts } \\
\text { Total contracts traded } \\
\text { domestically }\end{array}$} \\
\hline \multicolumn{6}{|l|}{ of which OTC } \\
\hline \multicolumn{6}{|l|}{$\begin{array}{l}\text { Total contracts held for } \\
\text { trading } 2 /\end{array}$} \\
\hline \multicolumn{6}{|l|}{$\begin{array}{l}\text { Total contracts held for } \\
\text { other than trading }\end{array}$} \\
\hline $\begin{array}{l}\text { Total contracts traded with } \\
\text { corporate sector }\end{array}$ & & & & & \\
\hline
\end{tabular}

1/ Excluding spot foreign exchange.

2/ For purposes of these totals, all derivative instruments of securities firms will be considered to be in the "contracts held for trading" category.

Notional amounts of exchange and OTC contracts by type help not only to monitor trends on the use of contracts by institution but also provide an idea of the credit, market, and liquidity risks. The higher the proportion of OTC contracts sold, the higher the credit risk, given the risk reduction mechanisms in the exchange. ${ }^{20}$ Also, the higher the volume of more

${ }^{20}$ At end 2003, notional outstanding of exchange-traded derivatives amounted to 20 percent of notional outstanding of OTC derivatives. 
sophisticated products, such as options and swaps other than plain vanilla products, the higher the potential for liquidity and market risks, as well as credit risk in case of positions sold. ${ }^{21}$ Regarding credit derivatives, all contracts are typically traded OTC. If the information is collected at the sector level, the notional amounts indicate the amount of risk unloaded (in case of banks and securities) or acquired (in case of insurance firms). Contracts held for other than trading typically reflect hedging strategies for market price movements affecting onbalance sheet items. Therefore, the higher the proportion of contracts held for trading, the larger the potential market risks for the institution. The comparison of contracts held for purposes other than trading to outstanding volumes of cash instruments for all the sectors, indicates whether certain risks, which can be affected by policy decisions, have been transferred.

Information regarding nominal amounts of exchange-traded and OTC contracts helps evaluate funding liquidity risks. Large positions in exchange-traded instruments increase liquidity demands for the daily cash settlements and for covering margin calls. To evaluate the market liquidity risk, it is important to have an idea of the overall size of the market for each product. Market liquidity risk depends on which market the product is traded, either domestically or international. Therefore, although not included in the CMF, Table 1 requests information on the volume of contracts traded domestically and internationally.

Finally, information on notionals traded with the corporate sector indicates the extent of corporate involvement on derivatives activities. When compared with the cash positions of corporations it provides an idea of the extent to which the corporate sector is hedged. Also assuming that all corporate derivatives are traded domestically, double counting of transactions between institutions in the reporting group can be eliminated by subtracting to the total the difference between domestically traded derivatives and derivatives traded with corporations. In this way, data can be compared with BIS global market data. ${ }^{22}$

Table 2 provides an indication of the liquidity of domestic markets by comparing outstanding amounts to turnover figures. This information is typically reported by the central bank and the exchange. The higher the concentration in the trading of products in relatively illiquid markets, the higher the liquidity risks. The higher the liquidity in the market, the easier it would be to unwind positions, although liquidity decreases substantially at times of systemic distress. While turnover data for exchange-traded derivatives are typically available from the exchange, data for OTC derivates are typically more difficult to obtain since such data are not normally collected for a firm's internal purposes. However, some central banks collect information on turnover. Although there is not a standardized set of indicators, information

\footnotetext{
${ }^{21}$ The proportion of exotic products on the book of institutions tends always to be small given that hedging those positions involves unbundling the different risks in exotic products and hedging them individually with plain vanilla products. Some market participants indicate that to hedge an exotic contract they need to contract three or four times its notional amount on plain vanilla products.

${ }^{22}$ See footnote 17.
} 
on the concentration of domestic markets (either quantitative or qualitative) should also be collected. ${ }^{23}$ Aggregating the information in Table 1 for all the sectors we can form an idea of the total volume of contracts traded by type of product, either exchange or OTC. Comparing this information with the volume of contracts traded domestically reported in Table 2, we can infer the OTC contracts, by type of product traded domestically and internationally. Liquidity of international OTC markets can be obtained from the BIS central bank survey of foreign exchange and derivatives market activity.

Table 2. Turnover and Notional Outstanding Amounts of Domestic Derivative Markets

\begin{tabular}{|c|c|c|c|c|c|c|c|c|c|c|}
\hline & \multicolumn{2}{|c|}{$\begin{array}{l}\text { Interest Rate } \\
\text { Contracts }\end{array}$} & \multicolumn{2}{|c|}{$\begin{array}{c}\text { Foreign Exchange } \\
\text { and Gold } \\
\text { Contracts }\end{array}$} & \multicolumn{2}{|c|}{$\begin{array}{l}\text { Commodity } \\
\text { contracts }\end{array}$} & \multicolumn{2}{|c|}{$\begin{array}{l}\text { Equity-linked } \\
\text { contracts }\end{array}$} & \multicolumn{2}{|c|}{$\begin{array}{c}\text { Credit } \\
\text { Derivatives }\end{array}$} \\
\hline & Turnover & Notional & Turnover & Notional & Turnover & Notional & Turnover & Notional & Turnover & Notional \\
\hline \multirow{2}{*}{\multicolumn{11}{|c|}{ (2) }} \\
\hline \multicolumn{3}{|l|}{ Forwards } & & & & & & & & \\
\hline \multicolumn{11}{|l|}{ Swaps } \\
\hline \multirow{2}{*}{\multicolumn{11}{|c|}{ Options }} \\
\hline \multicolumn{3}{|l|}{ CDS } & & & & & & & & \\
\hline \multicolumn{11}{|l|}{ Other } \\
\hline \multirow{2}{*}{\multicolumn{11}{|c|}{$\begin{array}{l}\text { Exchange- } \\
\text { traded }\end{array}$}} \\
\hline \multirow{2}{*}{\multicolumn{9}{|c|}{ Futures }} & & \\
\hline & & & & & & & & & & \\
\hline Options & & & & & & & & & & \\
\hline
\end{tabular}

The breakdown by remaining maturity collected in Table 3 provides additional information regarding policy effects and market risks since contracts of longer maturity are more sensitive to changes in the underlying. ${ }^{24}$ To the extent possible it would be desirable to compare the remaining maturity of derivative products held for hedging with the remaining maturity of cash positions. Information on derivatives by maturity bracket also provides indication of funding liquidity risks, although more detail analysis would be desirable. For example, large OTC positions hedge by exchange-traded contracts may result in liquidity pressures given the daily margin and cash requirements on these contracts. Information of OTC contracts subject to triggering agreements would also be useful to identify funding risks. $^{25}$

${ }^{23}$ In general concerns about the stability of the market increase if the market is highly concentrated. However, it could also be that trading in some segments by a small number of highly experienced firms might be more conducive to stability.

${ }^{24}$ For example, a five-year swap is more sensitive to a change in interest rates than a one year swap.

${ }^{25}$ Typically, triggering agreements require the liquidation of the contract or the posting of collateral by the counterparty if its credit rating is downgraded. 
Table 3. Derivative Contracts’ Notional Amounts by Remaining Maturity

\begin{tabular}{|c|c|c|c|}
\hline Contracts & One Year or Less & $\begin{array}{l}\text { Over One Year } \\
\text { through five years }\end{array}$ & Over five years \\
\hline \multicolumn{4}{|l|}{ Interest rate contracts } \\
\hline \multicolumn{4}{|l|}{ Exchange-traded } \\
\hline \multicolumn{4}{|c|}{ Foreign exchange and gold contracts } \\
\hline \multicolumn{4}{|l|}{ Exchange-traded } \\
\hline \multicolumn{4}{|l|}{ Commodity contracts } \\
\hline \multicolumn{4}{|l|}{ Exchange-traded } \\
\hline \multicolumn{4}{|l|}{ Equity-linked contracts } \\
\hline \multicolumn{4}{|l|}{ Exchange-traded } \\
\hline \multicolumn{4}{|l|}{ Other } \\
\hline Exchange-traded & & & \\
\hline
\end{tabular}

To assess credit exposures, Table 4 follows the gross market value (i.e., the replacement cost of the positions marked-to market) of OTC derivatives contracts. ${ }^{26}$ Gross positive market value excludes netting agreements, collateral, and guarantees.

A comparison of gross positive and negative values of contracts held for trading, aggregating the different sectors, indicates to which extent dealer gains and losses from derivatives balance each other (since dealers tend to account for the bulk of transactions) and also provides and indication of liquidity and market risks. ${ }^{27} \mathrm{~A}$ sharp change in the net market value of dealers positions, in the absence of significant changes in trading strategies, would indicate vulnerability to price shocks. If end-users hedge similar risks in similar directions market movements could cause large net losses for dealers, possibly leading to some of them withdrawing from the market. Information at the sectoral level indicates whether the sector is a net creditor or borrower. Potential credit exposure is the exposure of the contract that may be realized over its remaining life due to changes in prices, adding information on credit exposures.$^{28}$ Finally, changes in aggregate gross market value figures offer measures of the gross amount of wealth transferred and therefore provide an indication of market activity.

${ }^{26}$ Gross market value is calculated by adding gross positive market values of all reported trades to the gross negative market values of dealers trades with customers (excluding intragroup transactions).

${ }^{27}$ Notice that the fact that positions are balanced for the aggregate, does not imply that they are balanced for individual dealers. Ideally, individually information for the largest dealers should be also collected.

${ }^{28}$ See footnote 12 . 
Table 4. OTC Notional Amounts, Market Values and Potential Credit Exposures

\begin{tabular}{|c|c|c|c|c|c|}
\hline $\begin{array}{l}\text { Total Notionals, Market Values and } \\
\text { Potential Credit Exposure }\end{array}$ & $\begin{array}{l}\text { Interest rate } \\
\text { contracts }\end{array}$ & $\begin{array}{c}\text { Foreign } \\
\text { exchange and } \\
\text { gold } \\
\text { contracts }\end{array}$ & $\begin{array}{l}\text { Commodity } \\
\text { contracts }\end{array}$ & $\begin{array}{c}\text { Equity- } \\
\text { linked } \\
\text { contracts }\end{array}$ & $\begin{array}{c}\text { Credit } \\
\text { Derivatives }\end{array}$ \\
\hline \multicolumn{6}{|l|}{ Total notional amounts $1 /$} \\
\hline \multicolumn{6}{|l|}{ Contracts held for trading purposes $2 /$} \\
\hline \multicolumn{6}{|l|}{ Gross positive market value } \\
\hline \multicolumn{6}{|l|}{ Gross negative market value } \\
\hline \multicolumn{6}{|l|}{ Contracts held for other trading } \\
\hline \multicolumn{6}{|l|}{ Gross positive market value } \\
\hline \multicolumn{6}{|l|}{ Gross negative market value } \\
\hline Potential credit exposure 3/ & & & & & \\
\hline
\end{tabular}

1/ The "total notional amounts" reflected on this line are the sum of the notional amounts of the OTC contracts summarized in Table 1.

2/ For the purposes of these totals, all derivative instruments of securities firms will be considered to be in the "contracts held for trading" category.

3/ For banks, information on potential credit exposure should be in accordance with the Basel Capital Accord. Securities and insurance firms should use approaches acceptable to their higher regulator in estimating these amounts

To provide an indication of credit risk and off-balance sheet leverage in the market, Table 5 collects information on credit equivalent amounts by counterparty credit quality. To ensure exposures are appropriately measured, it is necessary to get an idea of the share of OTC contracts that are subject to netting agreements, and verify that there are no legal doubts regarding the enforceability of such agreements. Credit equivalent amounts are the sum of current and potential credit exposures, with current credit exposures reflecting the value of legally enforceable bilateral netting agreements. It is important to notice that while the credit risk arising form derivatives activities might be relatively small, entities defaulting on other derivative exposures are likely to default as well in the rest of their exposures vis-à-vis the system. Therefore, exposures of banks with corporations (most of the counterparties with a credit quality rating of 3. according to the Basel Capital Accord) should be view in the context not of the balance sheet of the financial system, but in the context of the balance sheet of the corporate sector. If the gross positive market value of derivatives activities in the corporate sector, which represents a gain for the financial institutions and a loss for the corporate sector, substantially affects the profitability or indebtedness of the corporate sector the risk for the financial system could be substantial. 
Table 5. Information on Credit Quality of OTC Derivative Contracts

\begin{tabular}{|c|c|c|c|c|c|}
\hline \multirow{2}{*}{\multicolumn{2}{|c|}{$\begin{array}{c}\text { Counterparty Credit } \\
\text { Quality 1/ }\end{array}$}} & \multicolumn{3}{|c|}{ Exposure Before Collateral and Guarantees } & \multirow{2}{*}{$\begin{array}{l}\text { Credit Equivalent } \\
\text { Amount After } \\
\text { Collateral } \\
\text { and Guarantees }\end{array}$} \\
\hline & & $\begin{array}{l}\text { Gross Positive } \\
\text { Market Value }\end{array}$ & $\begin{array}{c}\text { Current Credit } \\
\text { Exposure }\end{array}$ & $\begin{array}{l}\text { Potential Credit } \\
\text { Exposure }\end{array}$ & \\
\hline \multicolumn{6}{|c|}{ 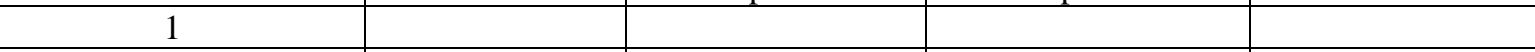 } \\
\hline \multicolumn{6}{|c|}{2} \\
\hline \multicolumn{6}{|c|}{3} \\
\hline \multicolumn{6}{|c|}{ Total } \\
\hline \multicolumn{6}{|c|}{$\begin{array}{l}\text { Note: When basing the above categories on ratings, an institution's equivalent internal credit grade ranking } \\
\text { may be used when investment ratings are not available. Moreover, in addition to using the credit quality } \\
\text { categories based on Basel Accord risk weights, bank supervisors may wish to assess the above information by } \\
\text { credit ratings assigned by external rating agencies or by an institution's internal credit grade rankings. }\end{array}$} \\
\hline 1. & \multicolumn{5}{|c|}{$\begin{array}{l}\text { For banks, category } 1 \text { identifies counterparties given a } 0 \text { percent risk weight under the Basel Capital } \\
\text { Accord. } \\
\text { For securities firms, category } 1 \text { identifies counterparties rated AA and above. }\end{array}$} \\
\hline 2. & \multicolumn{5}{|c|}{$\begin{array}{l}\text { For banks, category } 2 \text { identifies counterparties given a } 20 \text { percent risk weight under the Basel Capital } \\
\text { Accord. } \\
\text { For securities firms, category } 2 \text { identifies counterparties rated BBB and above. }\end{array}$} \\
\hline 3. & \multicolumn{5}{|c|}{$\begin{array}{l}\text { For banks, category } 3 \text { identifies counterparties given a } 50 \text { percent risk weight under the Basel Capital } \\
\text { Accord. } \\
\text { For securities firms, category } 3 \text { identifies counterparties rated below BBB. }\end{array}$} \\
\hline
\end{tabular}

Information on concentration of credit exposures at the institution level might be collected by supervisors. For example some supervisors might collect information on an institution by institution basis on the number of counterparties with current and potential exposures exceeding certain threshold (in term of assets or capital). Although this information is difficult to aggregate, at least qualitative information can be obtained regarding the credit concentration for the major holders of derivative products.

Finally, information on Table 6 indicates what is the value, both accounting and market values, of past-due derivatives and what have been the credit losses due to derivatives activities during the period.

Table 6: Information about Past-Due Derivatives and Credit Losses

\begin{tabular}{|l|l|}
\hline Book value of derivatives past-due 30-89 days & \\
\hline Book value of derivatives past-due 90 days or more & \\
\hline Gross positive market value of derivatives past-due 30-89 days & \\
\hline Gross positive market value of derivatives past-due 90 days or more & \\
\hline Credit losses on derivative instruments during the period & \\
\hline
\end{tabular}

In addition to the information contained in the set of tables following the CMF format, the $\mathrm{VaR}$ to capital ratio of the financial institutions provides valuable information regarding the sensitivity of banks exposures, including derivatives exposures, to shocks in market prices and volatilities. The ratio should be compiled for the VaR both under normal conditions and 
under stress scenarios such as September 112001 or the collapse of LTCM. Many financial institutions disclose this information in their investors' reports, but it can be also requested from supervisors in terms of a distribution (i.e., average, maximum, and minimum) of the highest value of the ratio during the period for the institutions considered.

The following table summarizes the proposed indicators, and its uses.

Table 7: Summary of Derivatives Data Elements and their Uses

\begin{tabular}{|c|c|}
\hline Element & Uses \\
\hline \multicolumn{2}{|l|}{ Notional values } \\
\hline \multicolumn{2}{|l|}{ OTC by contract type } \\
\hline Exchange by contract type & Market activity, uses of derivatives, credit \\
\hline OTC by market location & and market liquidity risks when combined \\
\hline Exchange by market location & with information on market liquidity \\
\hline By purpose of contract (i.e. trading or other) & \\
\hline Turnover to notional by product & Liquidity risk \\
\hline $\begin{array}{l}\text { Notional for risk categories by remaining } \\
\text { maturity }\end{array}$ & $\begin{array}{l}\text { Potential credit exposure, market and } \\
\text { liquidity risk }\end{array}$ \\
\hline Gross positive market value by risk category & Market activity, credit and liquidity risks \\
\hline Gross negative market value by risk category & Market activity, liquidity risks \\
\hline $\begin{array}{l}\text { Gross market value (net position) of trading } \\
\text { contracts }\end{array}$ & Market risk \\
\hline $\begin{array}{l}\text { Gross positive market value, current and } \\
\text { potential credit exposures and credit } \\
\text { equivalents by counterparty }\end{array}$ & $\begin{array}{l}\text { Credit risk and effects of mitigates such as } \\
\text { netting, collateral and guarantees }\end{array}$ \\
\hline $\begin{array}{l}\text { Institutions with credit exposures to the } 10 \\
\text { largest counterparties in excess of a given } \\
\text { threshold }\end{array}$ & Concentration of credit risk \\
\hline Book and market value of past-due derivatives & Credit risk \\
\hline VaR to capital ratio & Market risk \\
\hline
\end{tabular}




\section{Assessing the Quality of the Prudential and Supervisory Framework}

Domestic prudential norms should factor in the risks that financial firms incurred into through their derivatives activities. In the case of banks, at the minimum credit exposures incurred through Derivatives activities should be calculated according to the 1988 Basel Accord, and be included in the definition of total exposure to a counterparty for the purposes of limit setting. If capital risks charges are also applied, it should be checked that the treatment of derivatives for the calculation of those charges complies with the norms of the 1996 modification to the Basel Accord.

In addition, supervisory authorities need to be satisfied that the risk management process of the institution is adequate for the scope of its derivatives activities, and they should periodically require information on the practices. The Basel and IOSCO Committees have issued guidance on sound risk management of derivatives activities for use by supervisory authorities and financial institutions. ${ }^{29}$ Significant departures from these benchmark practices should be pointed out in the staff assessment of the adequacy of supervisory practices. In addition, institutions writing options or with substantial trading activities in exotic derivative products should have supervisory validation of their internal models. Supervisors should ensure that internal models of institutions dealing with exotic derivatives account adequately for additional risk factors such as implied volatility and correlation risks. It is fundamental that trading positions are reported to senior management as an integral part of the institutions risk management process, and that positions are prudently valued following procedures described in the new Basel Accord. ${ }^{30}$

Information on the adequacy of supervision of derivatives activities may be obtained from the assessment of compliance with the Basel Core Principles (BCP) for effective banking supervision, in particular in the assessment of BCP 12 that deals with market risk management. There is no international standard for the supervision of Derivatives activities of securities firms. However, poor prudential and supervisory practices identified in the assessment of compliance with the IOSCO objectives and principles for securities activities should be pointed out. Finally, the supervision of derivatives activities in insurance institutions is guided by the supervisory standards for derivatives issued by IAIS in 1998, currently under revision. Information regarding significant departures with respect to IAIS recommendations can be obtained from the assessment of compliance with IAIS insurance core principles.

In order to effectively monitor institution exposures to derivatives activities, supervisors should collect and monitor the relevant information. To the extent that derivatives activities are material within the institution, supervisors should collect the information described in the

${ }^{29}$ See Basel Committee (1994) and Technical Committee of IOSCO (1994).

${ }^{30}$ See Basel Committee (2004), page 151. 
CMF or at the minimum an information subset should be enough to assess the credit, market, and liquidity risk that arises from these activities. ${ }^{31}$ Shortcomings in the data collection and monitoring framework by the supervisory authorities should be pointed out in the assessment.

The Brockmeijer Report (1995), product of a working group of the Euro-Currency Standing Committee (ECSC) recommended that central banks monitor the role of derivatives markets in the trading and transfer of risks among agents with a view to assessing their possible implications for the conduct of monetary policy. ${ }^{32}$ From the macro prudential perspective, it recommended that central banks monitor developments in the concentration and liquidity of derivatives markets, as well as the price dynamics and the market linkages engendered by these markets. In those countries where statistics indicate substantial levels of derivatives activities, staff should assess the adequacy of the monitoring framework by the authority responsible for conducting monetary policy.

\section{ASSESSING THE RISK MITIGATION INFRASTRUCTURE}

Derivative exchanges have established mechanisms to reduce the risks involved in Derivatives activities. To the extent that exchange-traded derivatives are relevant for some sectors, it is important to evaluate the adequacy of exchange practices. In many countries at least an informal assessment of the adequate functioning of the exchange can be found in the FSAP report. At the core lies the evaluation of management of risks by the exchange clearing houses, and the management of settlement risks through the securities settlement system. Important departures from the IOSCO recommendations for central counter parties (CCPs) issued by IOSCO and the committee for payment and settlement systems (CPSS) should be pointed out. Information on such shortcomings might be obtained from the assessment of compliance with the recommendations for CPSS-IOSCO principles for securities settlement, typically conducted in the context of a financial system assessment program (FSAP). ${ }^{33}$

In the OTC markets the main instrument to mitigate risks is the use of legally enforceable master netting agreements. Verifying that the agreements used in the market are indeed legally enforceable is an essential part of assessing the adequacy of market arrangements. There are different modalities of netting contracts. The Basel Accord only allows for a reduction of credit risk in those cases in which the liquidator of a failed counterparty does not

\footnotetext{
${ }^{31}$ For a description of the CMF see Section II.

32 See Euro-Currency Standing Committee of the Central Banks of the Group of Ten Countries, (1996).

33 See Committee on Payment and Settlement Systems and Technical Committee of the International Organization of Securities Commissions, (2004).
} 
have the right to unbundle the netting contracts, demanding performance on those contracts favorable to his client and defaulting on the rest. Therefore information on the type of netting contracts that reduce credit exposure under the domestic bank capital requirements (provided that they are consistent with Basel norms) and the volume of contracts that incorporate those practices indicate the extent of risk mitigation. Typically credit exposures with the same counterparty can be netted out in the case of contracts subject to novation, although in some cases there is a phase-in period before the novation agreement can be recognized in the weighting framework, but not for contracts subject to close-out dates. ${ }^{34}$ To verify that the contracts really reduce credit risks, it is important to collect the opinions from domestic legal experts regarding the legality of netting in the bankruptcy procedures, and the enforceability of the contracts, based on default experiences. Lack of widespread use of legally enforceable risk mitigation techniques such as netting and pledging of collateral should be pointed out as an impediment for market development and a potential vulnerability in case credit exposures are not properly measured.

\section{Assessing TransparenCy OF Derivatives ACTIVITIES}

To assess the degree of transparency in the derivatives activities of financial institutions, it is necessary to evaluate the quality of disclosures of derivatives activities by institutions. There are two possible tools for the assessment of the adequacy of disclosure. One is comparing the disclosure of financial firms' derivatives activities with the recommendations of the Basel Committee and IOSCO, described in Section II. A second one, applicable only to banks, consists of comparing the disclosure of derivatives activities by banks on their annual reports with the requirements regarding disclosure of derivatives activities in the BIS survey of disclosure practices by international banks. ${ }^{35}$ This tool allows comparing the degree of disclosure by domestic institutions with the disclosure of the large international banks, which reflect best market practices. Box 1 indicates the questions formulated by the survey regarding derivatives and in particular credit derivatives.

${ }^{34}$ Netting by novation is a bilateral contract between two counterparties under which any obligation to each other to deliver a given currency on a given date is automatically amalgamated with all other obligations for the same currency and value date, legally substituting one single amount for the previous gross obligations. Close-out refers to a bilateral contract which provides that if one of the counterparties is wound up, the outstanding obligations between the two are accelerated and netted to determine the counterparty's net exposure.

35 The BIS sends a survey to supervisors in the main EU countries, plus the United States, Switzerland, and Japan regarding the disclosure practices of banks. Questions relate to several categories, from capital structure, adequacy and asset quality, to accounting and presentation techniques. Two categories refer to derivatives activities, one in particular referring to credit derivatives. The survey questions can be answered by yes, no, or not applicable if the issue is non material for the institution. The percentage of disclosure per category is measured as the ratio of yes's to the sum of yes's and no's. 
Regarding information disclosed by supervisors, at the minimum, the notional value of contracts traded differentiating by broad risk category, both in the domestic OTC and exchange markets, should be published. The information will allow participants to asses the relative importance of their positions to avoid excessive market concentration. Indications of market liquidity by risk factor and type of product, for both OTC and exchange-traded products also provide valuable information to market participants regarding the scope for liquidating positions. 


\section{Box 1. BIS Survey of Disclosure Practices by Banks: Disclosure of Derivatives Activities}

\section{Credit Derivatives Disclosures}

Qualitative disclosures:

- $\quad$ Does the bank discuss how credit derivatives are used, including strategy and objectives?

Quantitative disclosures:

- $\quad$ Does the bank disclose the notional amounts and fair value of credit derivatives?

- $\quad$ Does the bank disclose quantitative information about the effect of credit enhancements on counterparty credit exposures?

- $\quad$ Does the bank disclose the amount of credit risk bought or sold using credit derivaties?

- $\quad$ Does the bank list breakdown of credit derivatives by type of instrument (e.g., total return swaps, credit default swaps or other credit derivatives)?

- $\quad$ Does the bank disclose information on the effect of credit enhancement on the bank's counterparty exposure from OTC contracts?

\section{Derivatives (other than Credit Derivatives) Disclosures}

Qualitative disclosures:

- $\quad$ Does the bank discuss the objectives for use of nontrading derivatives?

- $\quad$ Does the bank describe how derivaties are used to hedge risks (strategies)?

- $\quad$ Does the bank discuss the overall business objectives of tradign activities and strategies for achieving those objectives?

Quantitative disclosures:

- $\quad$ Does the bank disclose the gross positive market value of derivatives?

- $\quad$ Does the bank disclose the gross negative market value of derivatives?

- $\quad$ Does the bank provide summary information about the effect of nontrading derivatives on earnings of off-balance sheet (hedging) positions held by the organization (e.g., to manage interest rate risk, currency risk, and other risks)?

- $\quad$ Does the bank disclose the quantitative effect of legally enforceable bilateral and multilateral netting agreements?

- $\quad$ Does the bank provide end-of-period and average notional and market values for trading portfoliso and nontrading portfolios?

Does the bank disclose future potential exposures for derivatives, where appropriate? 


\section{References}

Bank for International Settlements, 2001, "Recommendations for Securities Settlement Systems," Committee on Payments and Securities Settlements and Technical Committee of the International Organization of Securities Commission, November.

— 2004, "Recommendations for Central Counterparties," Committee on Payments and Securities Settlements and Technical Committee of the International Organization of Securities Commission, BIS Consultative paper, March.

Basel Committee on Banking Supervision, 1997, “Core Principles for Effective Banking Supervision," September.

Basel Committee and IOSCO, 1999, "Recommendations For Public Disclosure of Trading and Derivatives activities of Banks and Securities Firms,” October.

Basel Committee, 1988, “International Convergence of Capital Measurement and Capital Standards,” July.

—_, 1994, “Risk Management Guidelines for Derivatives,” July.

—_, 1995, “An Internal Model-Based Approach to Market Risk Capital Requirements,” April.

— (updated April 1998).

_ 1998, "Framework for Supervisory Information about Derivatives and Trading Activities," September.

__ 2003, “Public Disclosures by Banks: Results of the 2001 Disclosure Survey,” May.

_ June.

Committee on Global Financial System (CGFS), 1994, “Compendium of Annexes to the Report on Macroeconomic and Monetary Policy Issues Raised by the Growth of Derivatives Markets,” November.

Committee on Payment and Settlement Systems and Technical Committee of the International Organization of Securities Commissions (IOSCO), 2004, "Recommendations for Central Counterparties,” November. 
Counterparty Risk Management Group, 1999, “Improving Counterparty Risk Management Practices,” June.

Euro-Currency Standing Committee of the Central Banks of the Group of Ten Countries, 1996, “Proposals for improving Global Derivatives Market Statistics,” July.

International Association of Insurance Supervision (IAIS), 1998, “Supervisory Standard on Derivatives," October.

__ 2002, “Guidance Paper on Public Disclosures by Insurers,” January.

— 2003, "IAIS Paper on Credit Risk Transfer between Insurance, Banking, and Other Financial Sectors Presented to the Financial Stability Forum,” March.

OICU-IOSCO, 2003, “Objectives and Principles of Securities Regulation,” May.

Technical Committee of IOSCO, 1994, “Operational and Financial Risk Management Control Mechanisms for OTC Derivatives of Regulated Securities Firms”, July. 